The University of Maine

\title{
DigitalCommons@UMaine
}

Earth Science Faculty Scholarship

Earth Sciences

9-1-1996

\section{Depletion of Atmospheric Nitrate and Chloride as a Consequence of the Toba Volcanic Eruption}

Q. Yang

Paul Andrew Mayewski

University of Maine, paul.mayewski@maine.edu

G. A. Zielinski

M. Twickler

K. C. Taylor

Follow this and additional works at: https://digitalcommons.library.umaine.edu/ers_facpub

Part of the Climate Commons, Geochemistry Commons, Glaciology Commons, $\underline{\text { Hydrology }}$ Commons, and the Volcanology Commons

\section{Repository Citation}

Yang, Q.; Mayewski, Paul Andrew; Zielinski, G. A.; Twickler, M.; and Taylor, K. C., "Depletion of Atmospheric Nitrate and Chloride as a Consequence of the Toba Volcanic Eruption" (1996). Earth Science Faculty Scholarship. 194.

https://digitalcommons.library.umaine.edu/ers_facpub/194 


\title{
Depletion of atmospheric nitrate and chloride as a consequence of the Toba volcanic eruption
}

\author{
Q. Yang, P. A. Mayewski, G. A. Zielinski, and M. Twickler \\ Climate Change Research Center, University of New Hampshire, Durham, NH 03824, U.S.A.
}

\author{
K. C. Taylor \\ Desert Research Institute, University of Nevada, Reno, NV 89506, U.S.A.
}

\begin{abstract}
Continuous measurements of $\mathrm{SO}_{4}{ }^{2-}$ and electrical conductivity (ECM) along the GISP2 ice core record the Toba mega-eruption at a depth 2590.95 to $2091.25 \mathrm{~m}(71,000 \pm 5000$ years ago). Major chemical species were analyzed at a resolution of $1 \mathrm{~cm}$ per sample for this section. An 6-year long period with extremely high volcanic $\mathrm{SO}_{4}{ }^{2-}$ coincident with a $94 \%$ depletion of nitrate and $63 \%$ depletion of chloride is observed at the depth of the Toba horizon. Such a reduction of chloride in a volcanic layer preserved in an ice core has not been observed in any previous studies. The nearly complete depletion of nitrate (to 5 $\mathrm{ppb}$ ) encountered at the Toba level is the lowest value in the entire $\sim 250,000$ years of the GISP2 ice core record. We propose possible mechanisms to explain the depletion of nitrate and chloride resulting from this mega-eruption.
\end{abstract}

\section{Introduction}

The eruption of Toba, Sumatra, between 68,000 and 75,000 years ago is the largest known explosive volcanic eruption in the late Quaternary [Rose and Chesner, 1987; Chesner et al., 1991; Rampino and Self, 1992]. During the Toba eruption, the large amount of volcanic ash and sulfur gases (about $10^{15} \mathrm{~g}$ each of fine ash and sulfur gases that rose to heights of $27-37 \mathrm{~km}$ [Rampino and Self, 1992]) emitted into the stratosphere formed a blanket that may have significantly reduced sunlight to a state of darkness [Chesner et al., 1991; Rampino et al., 1988]. Previous assessments of the atmospheric impact of the Toba eruption have been relied on estimates of the amount of sulfur $\left(10^{16} \mathrm{~g} \mathrm{H}_{2} \mathrm{SO}_{4}\right)$ emitted as approximated by mineralogical studies of the eruptive products [Rose and Chesner, 1990] or have been based on the gas emitted/volume of erupted magma ratio for several historical eruptions [Rampino et al., 1988; Rampino and self, 1992]. Now, estimates from the GISP2 ice core are that $2-410^{15} \mathrm{~g}$ of $\mathrm{H}_{2} \mathrm{SO}_{4}$ aerosol were emitted into stratosphere [Zielinski et al., 1996]. All of these estimates are within an order of magnitude, especially considering the different approaches used. This single volcanic eruption is believed to have caused a several year decrease of $-3-5^{\circ} \mathrm{C}$ in annual surface temperature for northern hemisphere [Rampino and Self, 1992].

Historical volcanic eruptions can be identified in ice cores through the preserved high concentrations in the continuous measurement of $\mathrm{SO}_{4}{ }^{2-}$ and electrical conductivity [e.g. Hammer, 1977; Taylor et al., 1992; Zielinski et al., 1994]. The Toba event was identified at $\sim 2591.10 \mathrm{~m}(71,000 \pm 5000$ years ago $)$ in the

Copyright 1996 by the American Geophysical Union.

Paper number 96GL02201

0094-8534/96/96GL-02201\$05.00
GISP2 ice core (3053.44 meter deep) from central Greenland $\left(76.6^{\circ} \mathrm{N} ; 38.5^{\circ} \mathrm{W}\right)$ [Zielinski, et al., 1996]. It was suggested that magnitude and longevity of the atmospheric loading during the Toba eruption may have led directly to enhanced cooling during the initial two centuries of an $\sim 1000$-year cooling event [Zielinski et al., 1996].

In addition to the climatic impact of volcanic eruptions, atmospheric photochemistry can be severely influenced by the release of large amounts of sulfur and fine ash into the atmosphere [Hofmann, 1987; Hofmann and Solomon, 1989; Brasseur and Granier, 1992]. Based on a one dimensional sulfate aerosol model and recent laboratory data, Bekki (1994) suggested that substantial denitrification of the lower polar stratosphere occurred during the Toba eruption. In the work presented here, the Toba horizon preserved in the GISP2 ice core was utilized to investigate the influence of this mega-eruption on changes in the concentration of several chemical species $\left(\mathrm{SO}_{4}{ }^{2-}, \mathrm{Cl}^{-}\right.$and $\left.\mathrm{NO}_{3}\right)$.

\section{Results and Discussion}

Continuous measurements of $\mathrm{SO}_{4}{ }^{2-}$ and electrical conductivity (ECM) along the GISP2 ice core record a large volcanic signal at a depth 2590.95 to $2091.25 \mathrm{~m}(71,000 \pm 5000$ years ago). It is believed that this signal is from the Toba megaeruption [Zielinski et al., 1996]. Major chemical species were analyzed at a resolution of $1 \mathrm{~cm}$ per sample for this section. Details on the analytical procedures were given in Mayewski et al. (1987) and Buck et al. (1992). Concentrations of $\mathrm{Na}^{+}, \mathrm{Cl}^{-}$, $\mathrm{NO}_{3}{ }^{-}$, non-seasalt $\mathrm{SO}_{4}{ }^{2-}$, and the ratio of $\mathrm{Cl}^{-} / \mathrm{Na}^{+}$of the section covering \pm 20 years around the Toba signal are plotted on Figure 1. The non-seasalt $\mathrm{SO}_{4}{ }^{2-}$ peak value of $1935.3 \mathrm{ppb}(40.57$ $\mu \mathrm{eq} / \mathrm{kg})$ is the highest concentration detected in the entire $\sim 250,000$ years of the GISP2 ice core record. A mean $\mathrm{NO}_{3}$. concentration of $5 \pm 1.0 \mathrm{ppb}$ at this level persists for $\sim 6$ years ( 1.5 years/sample [Zielinski et al., 1996]), the lowest level in the entire GISP2 record. A mean value of $83.4 \pm 5.5 \mathrm{ppb}$ of $\mathrm{NO}_{3}{ }^{-}$ characterizes the period prior to the eruption. In addition, $\mathrm{Cl}^{-}$ concentration during the eruption is $24.7 \pm 4.23$ versus a preeruption mean of $66.4 \pm 3.0 \mathrm{ppb}$ and the ratio of $\mathrm{Cl}^{-} / \mathrm{Na}^{+}$is 0.75 \pm 0.06 versus a pre-eruption mean of $1.87 \pm 0.09$. Thus $\mathrm{NO}_{3}{ }^{-}, \mathrm{Cl}^{-}$ and $\mathrm{Cl}^{-} \mathrm{Na}^{+}$are all dramatically decreased in section of the ice core containing high amounts of volcanic $\mathrm{SO}_{4}{ }^{2-}$.

However, no volcanic glasses have been found from the Toba horizon in the GISP2 ice core [Zielinski et al., 1996] despite the suggestion that Toba eruption may force climatic cooling on century time scales [e.g., Rampino and Self, 1992; Zielinski et al., 1996]. This drastic climatic disturbances in the northern hemisphere due to the explosive eruption was preserved in the GISP2 ice core [Zielinski et al., 1996]. The large amount of 


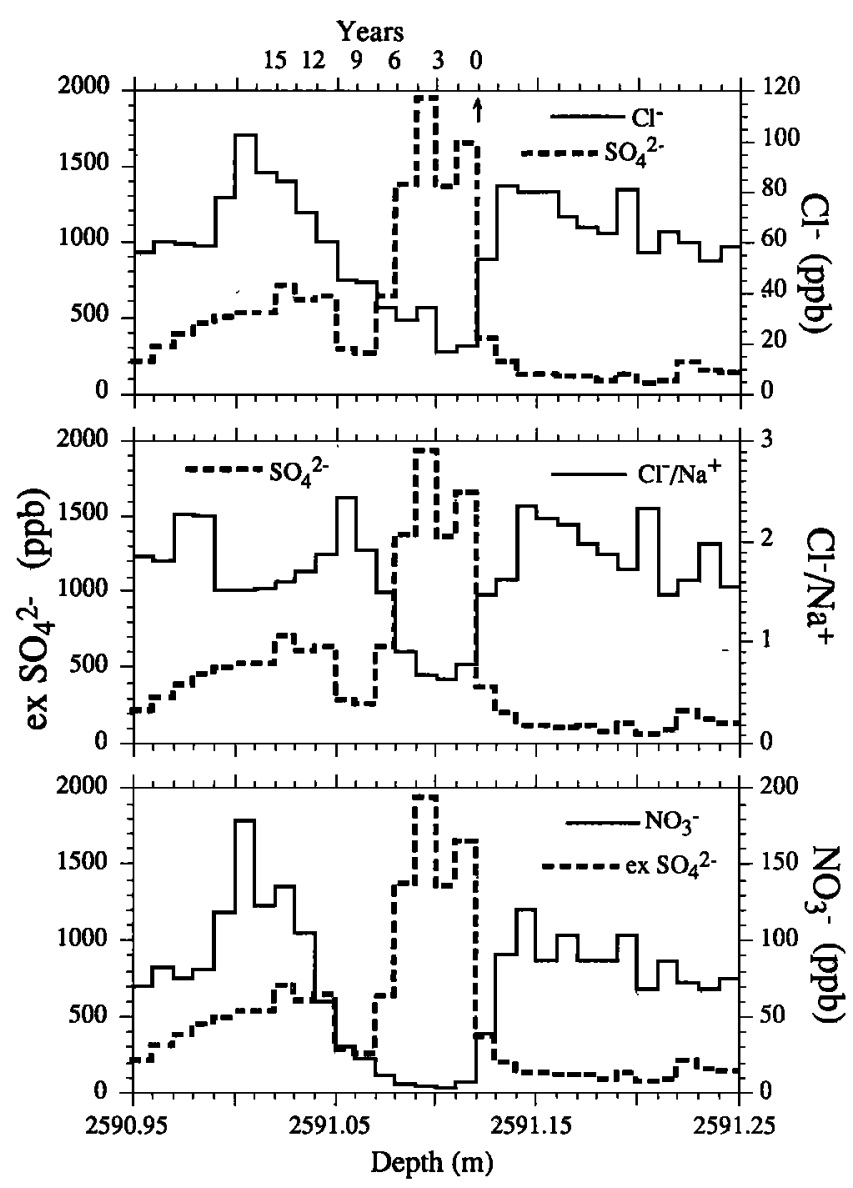

Figure 1. Concentrations (ppb) of $\mathrm{Cl}^{-}, \mathrm{NO}_{3}{ }^{-}$, and the ratio of $\mathrm{Cl}^{-}$ $\mathrm{Na}^{+}$plus non-seasalt $\mathrm{SO}_{4}{ }^{2-}$ for the Toba signal in the GISP2 ice core at $2590.95-2591.25 \mathrm{~m}(71,000 \pm 5000)$. Time scales are after Zielinski et al. [1996]

volcanic $\mathrm{H}_{2} \mathrm{SO}_{4}$ with no volcanic glass suggests that $\mathrm{H}_{2} \mathrm{SO}_{4}$ aerosols play a more important role than ash in climatic disturbances [Rampino and Self, 1992].

To investigate the possible causes for depletion $\mathrm{Cl}^{-}$and $\mathrm{NO}_{3}^{-}$ in this section core, we first considered whether the depletion of $\mathrm{Cl}^{-}$and $\mathrm{NO}_{3}{ }^{-}$results from diffusion taking place in the core as $\mathrm{De}$ Angelis and Legrand [1994] suggested for fluoride. The fluoride was observed to be subsequently excluded from a volcanic acidic layers in the ice cores from Greenland ice sheet [Angelis and Legrand, 1994]. The amount of volatile $\mathrm{HCl}$ released from a major volcanic eruption can be of the same order of magnitude as modern anthropogenic emissions of $\mathrm{Cl}^{-}$into the atmosphere [Legrand and Delmas, 1988; Tabazadeh and Turco, 1993]. Explosive volcanic eruptions (e.g., Krakatoa, $1883 \mathrm{AD}$; Tambora, $1815 \mathrm{AD})$ have released several teragrams $\left(10^{6} \mathrm{t}\right)$ of $\mathrm{HCl}$ into the atmosphere [Legrand and Delmas, 1988; Devine, 1984]. However, elevated levels of $\mathrm{Cl}^{-}$associated with these volcanic events are not observed in Antarctic ice cores and levels in Greenland ice cores are insignificant despite the distinct elevated concentrations of $\mathrm{SO}_{4}{ }^{2-}$ [Legrand and Delmas, 1988; Laj, 1993]. The absence of volcanic $\mathrm{Cl}^{-}$in these ice cores has been attributed to the rapid scavenging of $\mathrm{HCl}$ in the local troposphere. Plume dynamics and thermodynamics modeling suggest that water released from a major volcanic eruption will remove most of the volcanic emissions of $\mathrm{HCl}$ from the troposphere, thus preventing substantial contributions of $\mathrm{HCl}$ into the stratosphere [Tabazadeh and Turco, 1993].
Above arguments suggest that volcanic eruptions may be not marked by elevated $\mathrm{Cl}^{-}$concentrations in ice core records. Those arguments do not, however, explain the remarkable reduction of $\mathrm{Cl}^{-}$related to the Toba $\mathrm{SO}_{4}^{2-}$ increase (Figure 1). The postdepositional movement of $\mathrm{HCl}$ in a volcanic layer in ice cores has never been observed and $\mathrm{Cl}^{-}$spikes are considered to be indicators of volcanic signal in ice cores [Lyons et al., 1990]. Therefore it is clear that $\mathrm{Cl}^{-}$depletion in the GISP2 horizon must have occurred, at least in part, prior to deposition.

Reduction of $\mathrm{NO}_{3}{ }^{-}$has been observed along with volcanically deposited $\mathrm{SO}_{4}{ }^{2-}$ in Greenland [Laj et al., 1993] and Antarctic ice cores [Legrand and Kirchner, 1990]. The magnitude of $\mathrm{NO}_{3}{ }^{-}$ reductions is, however, not comparable to the nearly complete 6-year depletion observed in this study. It has been reported that surface snow over Greenland contains elevated concentrations of both $\mathrm{NO}_{3}{ }^{-}$and $\mathrm{SO}_{4}{ }^{2-}$ [Laj et al., 1992; Whitlow et al., 1992; Yang et al., in press]. These observations suggested that high concentrations of $\mathrm{NO}_{3}{ }^{\circ}$ and $\mathrm{SO}_{4}{ }^{2-}$ can be preserved in the snow so that a direct chemical interaction between these two anions may be ruled out [Laj et al., 1993]. Even though we do not rule out the possibility of depletion of $\mathrm{Cl}^{-}$and $\mathrm{NO}_{3}{ }^{-}$due to the extremely acidic condition in the Toba horizon, there must be an atmospheric photochemistry perturbation during such an explosive volcanic eruption. Since both $\mathrm{Cl}^{-}$and $\mathrm{NO}_{\mathbf{x}}$ (a precursor of $\mathrm{NO}_{3}{ }^{-}$) are important species in atmospheric photochemistry, we propose a possible mechanisms for the atmospheric depletion of the $\mathrm{Cl}^{-}$and $\mathrm{NO}_{3}{ }^{-}$as evidenced by the minima of two species in the GISP2 ice core.

Sea-salt is the primary source of $\mathrm{Cl}^{-}$deposited in polar snow and ice [Legrand and Delmas, 1988]. Heterogeneous reactions involving sea-salt aerosol in the marine troposphere are the major global source for volatile inorganic chloride [Keene et al., 1990]. The reaction between sea-salt aerosol and $\mathrm{H}_{2} \mathrm{SO}_{4}$ is believed to produce most of the volatile $\mathrm{HCl}$ in the atmosphere [Legrand and Delmas, 1988; Brimblecombe and Clegg, 1988]

$$
2 \mathrm{NaCl}+\mathrm{H}_{2} \mathrm{SO}_{4} \rightarrow 2 \mathrm{HCl}_{(\mathrm{g})}+\mathrm{Na}_{2} \mathrm{SO}_{4}
$$

This mechanism causes a $\mathrm{Cl}^{-}$deficit in transported sea-salt aerosols so that the $\mathrm{Cl}^{-} / \mathrm{Na}^{+}$ratio in ice cores can be lower than that in mean seawater (1.8 by weight) [Legrand and Delmas, 1988]. Since $\mathrm{SO}_{4}{ }^{2-}$ emissions from Toba lasted -6 years and were global in extent [Zielinski et al., 1996], equation (1) may explain part of the $\mathrm{Cl}^{-}$deficit related to this event (Figure 1).

Following the Toba eruption, direct surface reactions between sea-salt aerosol and $\mathrm{O}_{3}$ in the marine troposphere may have occurred through the reaction [Keene et al., 1990]:

$$
2 \mathrm{Cl}_{(\mathrm{p})}+\mathrm{O}_{3}+\mathrm{H}_{2} \mathrm{O} \rightarrow \mathrm{Cl}_{2(\mathrm{~g})}+2 \mathrm{OH}^{-}+\mathrm{O}_{2(\mathrm{~g})}
$$

Under nonvolcanic conditions, $\mathrm{Cl}_{2}$ is rapidly converted to $\mathrm{HCl}$ via $\mathrm{Cl}$ atoms $\left(\mathrm{Cl}^{\circ}\right)$ photochemically and with the eventual recapture of $\mathrm{HCl}$ by sea-salt aerosols. During the Toba eruption, a decrease in sunlight to near darkness may have prevented $\mathrm{Cl}_{2}$ from converting to $\mathrm{HCl}$ [Rampino et al., 1988; Chesner et al., 1991]. There is, however, as indicated in Figure 1, a Cl- peak following the eruption. This may suggest that after the Toba eruption, the atmospheric reservoir of $\mathrm{Cl}_{2}$ built up during the Toba eruption was photolyzed to $\mathrm{HCl}$. Thus, depletion of the $\mathrm{Cl}^{-}$ may have resulted from the combined effects of loss of $\mathrm{Cl}^{-}$ through reaction (1), reduced sunlight preventing chlorine recycling in the atmosphere (Equation 2).

Although sources and deposition pathways of $\mathrm{NO}_{3}^{-}$in Greenland snow are not well understood [Dibb et al., 1994; Yang et al., 1995], it is clear that the $\mathrm{OH}$ radical and $\mathrm{NO}_{x}$ play 
important roles in the formation of $\mathrm{HNO}_{3}$ in the ambient atmosphere over Greenland [Logan, 1983; Yang et al., 1995].

It is estimated that $\sim 3 \times 10^{15} \mathrm{~g}$ of $\mathrm{H}_{2} \mathrm{~S}$ and $\mathrm{SO}_{2}$ were released into the atmosphere during the Toba eruption [Rampino and Self, 1992]. Potential $\mathrm{SO}_{2}$ oxidants include the radicals $\mathrm{OH}, \mathrm{HO}_{2}$, $\mathrm{RO}_{2}$, and $\mathrm{H}_{2} \mathrm{O}_{2}$. $\mathrm{OH}$ may have been consumed through the reaction [Warneck, 1988]:

$$
\begin{gathered}
\mathrm{OH}+\mathrm{SO}_{2} \rightarrow \mathrm{HOSO}_{2} \\
\mathrm{HOSO}_{2}+\mathrm{O}_{2} \rightarrow \mathrm{SO}_{3}+\mathrm{H}_{2} \mathrm{O} \\
\mathrm{SO}_{3}+\mathrm{H}_{2} \mathrm{O} \rightarrow \mathrm{H}_{2} \mathrm{SO}_{4}
\end{gathered}
$$

During nonvolcanic periods, there is no net consumption of $\mathrm{OH}$ since it is recycled through the reaction [Calvert and Stockwell, 1984]:

$$
\mathrm{HO}_{2}+\mathrm{NO} \rightarrow \mathrm{NO}_{2}+\mathrm{OH}
$$

However, it has been suggested that $\mathrm{OH}$ recycling is interrupted following a large volcanic eruption since the atmosphere is overwhelmed by $\mathrm{SO}_{2}$ [Laj et al., 1993]. Rampino and Self (1992) and Zielinski et al. (1996) suggested that the Toba eruption produced as much as $10^{16} \mathrm{~g} \mathrm{H}_{2} \mathrm{SO}_{4}$ aerosol in the stratosphere. Therefore, $\mathrm{OH}$ was presumably consumed via oxidation with $\mathrm{SO}_{2}$. In fact, reaction (6) may have been eliminated following the Toba eruption because $\mathrm{HO}_{2}$ is also a potential oxidant which may have been consumed by the large amount of $\mathrm{SO}_{2}$ released from the Toba eruption [Warneck, 1988]. On the other hand, the state of reduced sunlight following the eruption may have caused changes in the stratosphere's radiative field. Thus, there may have been subsequent loss of $\mathrm{OH}$ resulting in a decrease in UV radiation [Legrand and Kirchner, 1990].

Following the Toba eruption, thermal convection may have decreased dramatically due to reduced heating in the atmosphere. As a consequence the $\mathrm{NO}_{\mathrm{x}}$ formed by lightning and from soil microbial activities at low latitudes would not be as easily incorporated into the atmosphere and levels near Greenland could have been decreased notably. In this case, subsequent loss of $\mathrm{OH}$ due to changes in UV radiation and $\mathrm{OH}$ consumed by $\mathrm{SO}_{2}$ following the eruption in the atmosphere, in addition to reduced $\mathrm{NO}_{\mathrm{x}}$ sources at low latitudes, may have caused a near complete depletion of $\mathrm{HNO}_{3}$ in the atmosphere over Greenland as eventually recorded in the GISP2 ice core (Figure. 1).

Ozone destruction was observed through heterogeneous chemistry following a volcanic eruption [Hofmann, 1987; Hofmann and Solomon, 1989; Brasseur and Granier, 1992]. It was also suggested by Bekki (1994) that denitrification (i.e., the irreversible removal of nitrogen species from the higher to lower altitude in the polar stratosphere) is enhanced by sulfate aerosol released from the volcanic activities. Bekki (1994) used a one dimension sulfate aerosol model to predict that substantial denitrification of the polar lower stratosphere occurred during the Toba eruption. If this is the case, $\mathrm{HNO}_{3}$ derived from such denitrification would be eventually scavenged by snow flakes. Consequently, elevated $\mathrm{HNO}_{3}$ concentration should have been found in the Toba horizon of the GISP2 ice core. Our data in Figure 1, however, do not provide evidence to support Bekki's hypothesis, at least, the denitrification was not as strong as predicted (Figure 1).

\section{Summary}

Our data provide an atmospheric reconstruction of the chlorine and nitrogen cycling response to the impact of the Toba mega-volcanic eruption. We agree that the Toba eruption not only caused a volcanic winter effect [Rampino et al., 1988], but that it also disturbed photochemical reactions in the atmosphere. Further, due to the evidence that extremely acidic $\mathrm{SO}_{4}{ }^{2-}$ layer with no volcanic glasses in the GISP2 ice core, we suggest that $\mathrm{SO}_{4}{ }^{2-}$ aerosols influence the climate disturbance. Although $\mathrm{Cl}^{-}$ and $\mathrm{NO}_{3}{ }^{-}$in a volcanic layer have never been reported to be removed due to their association with strongly acidic layer, we cannot rule out the possibility that $\mathrm{Cl}^{-}$and $\mathrm{NO}_{3}^{-}$were removed by post-deposition process related to this extremely acidic layer. We suggest that the depletion of $\mathrm{Cl}^{-}$and $\mathrm{NO}_{3}{ }^{-}$observed in the Toba horizon in the GISP2 ice core was a result of changes in the atmospheric chemistry and removal from the ice layer due to the extreme acidic condition. This and other research on the impact of volcanic aerosols on changes in atmospheric photochemistry and dynamics provide further information to assess the impact of climatic and atmospheric environmental changes following volcanic eruptions.

Acknowledgements. We thank S. Whitlow and R. Talbot for their valuable suggestions. We are also grateful for the assistance of the GISP2 Science Management Office (University of New Hampshire) and the Polar Ice Coring Office (University of Alaska). Support for this work was provided by the National Science Foundation.

\section{References}

Bekki S., Denitrification mechanism of the polar winter stratosphere by major volcanic eruptions, J. Geophy. Res. 99, 18,871-18,878, 1994.

Brasseur G. and C. Granier, Mount Pinatubo aerosols, Chlorofluorocarbons, and ozone depletion, Science 257, 1239--1242, 1992.

Brimblecombe P. and S. L. Clegg, The solubility and behaviour of acid gases in the marine aerosol, J. Atmos. Chem. 7, 1-18, 1988.

Buck C. F., P. A. Mayewski, M. J. Spencer, S. Whitlow, M. S. Twickler, and D. Barrett, Determination of major ions in snow and ice cores by ion chromatography, Journal of Chromatography 594, 225-228, 1992.

Calvert J. G. and W. R. Stockwell, Mechanism and rates of the gas-phase oxidations of sulfur dioxides and nitrogen oxides in the atmosphere, in SO2, NO and NO2 and Oxidation Mechanisms: Atmospheric Considerations, edited by J. G. Calvert, pp. 1-62. Butterworth, Boston, 1984.

Chesner C. A., W. I. Rose, A. Deino, R. Drake, and J. A. Westgate, Eruptive history of Earth's largest Quaternary caldera (Toba, Indonesia) clarified, Geology 19, 200-203, 1991.

De Angelis M. and M. Legrand, Origins and variations of fluoride in Greenland precipitation, J. Geophys. Res. 99, 1157-1172, 1994.

Devine J. D., H. Sigurdsson, A. N. Davis, and S. Self, Estimates of sulfur and chlorine yield to the atmosphere from volcanic eruptions and potential climatic effects, J. Geophys. Res. 89, 6309-6325, 1984.

Dibb J. E., R. W. Talbot, and M. H. Bergin, Soluble acidic species in air and snow at Summit, Greenland, Geophs. Res. Lett. 21, 1627-1630, 1994.

Hammer C. U., Past volcanism revealed by Greenland ice sheet impurities, Nature 270, 230-235, 1977.

Hofmann D. and S. Solomans, Ozone destruction through heterogeneous chemistry following the eruption of $\mathrm{El} \mathrm{Chicon,}$ J. Geophys. Res. 94, 5029-5041, 1989.

Hofmann D., Perturbations to the global atmosphere associated with the El Chichon volcanic eruption of 1982, Reviews of Geophysics 25, 743-759, 1987.

Keene W. C., A. P. Pszenny, D. J. Jacob, R. A. Duce, J. N. Galloway, J. J. Schultz-Tokos, H. Sievering, and J. F. 
Boatman, The geochemical cycling of reactive chlorine through the marine troposphere, GlobalBiogeochemical Cycles 4, 407-430, 1990.

Laj $P$., Changing sources of impurities to the Greenland ice sheet over the last 250 years, Atmos. Environ. 26A, 2627-2640, 1992.

Laj P., J. M. Palais, J. E. Gardner, and H. Sigurdsson, Modified HNO3 seasonality in volcanic layers of a polar ice core: Snow-pack effect or photochemical perturbation, JAtmos. Chem. 16, 219-230, 1993.

Legrand M. and R. Delmas, Formation of $\mathrm{HCl}$ in the Antarctic Atmosphere, J. Geophys. Res. 93, 7153-7168, 1988. Legrand M. R. and S. Kirchner, Origins and variations of nitrate in south polar precipitation, J. Geophys. Res. 95, 3493-3507, 1990.

Logan J. A., Nitrogen oxides in the troposphere: Global and regional budgets, J. Geophys. Res. 88, 10,785-10,807, 1983

Lyons W. B., P. A. Mayewski, M. J. Spencer, M. S. Twickler, and T. E. Graedel, A Northern Hemispheric volcanic chemistry (1869-1984) record and climatic implications using a south Greenland ice core, Annals of Glaciology 14, 176$182,1990$.

Mayewski P. A., M. J. Spencer, W. B. Lyons, and M. S. Twickler, seasonal and spatial rends in south Greenland snow chemistry, Atmos. Environ. 21, 863-869, 1987.

Rampino M. R. and S. Self, Volcanic winter and accelerated glaciation following the Toba super-eruption, Nature 359 , 50-52, 1992.

Rampino M. R., S. Self, and R. B. Stothers, Volcanic winters, Ann. Rev. Earth Planet. Sci. 16, 73-99, 1988.

Rose W. I. and C. A. Chesner, Dispersal of ash in the great Toba eruption, $75 \mathrm{ka}$, Geology 15, 73-99, 1987.

Rose W. I. and C. A. Chesner, Worldwide dispersal of ash and gases from earth's largest known eruption: Toba, Sumatra, 75ka, Palaeogeorg., Paleoclim., Palaeoecol. 89, 913-917, 1990.

Tabazadeh A. and R. P. Turco, Stratospheric chlorine injection by volcanic eruptions: $\mathrm{HCl}$ scavenging and implications for Ozone, Science 260, 1,082-1,086, 1993.
Taylor K., R. B. Alley, J. Fiacco, P. M. Grootes, G. W. Lamorey, P. A. Mayewski, and M. J. Spencer, Ice core dating and chemistry by direct-current electrical conductivity, $J$. Glaciol. 38, 325-332, 1992.

Warneck P., Chemistry of the Natural Atmosphere. Academic Press, San Diego, Calif., 1988.

Whitlow S., P. A. Mayewski, and J. Dibb, A comparison of major chemical species seasonal concentration and accumulation at the South Pole and Summit, Greenland, Atmos. Environ. 26A, 2045-2054, 1992.

Yang Q., P. A. Mayewski, E. Linder, S. Whitlow, and M.Twickler, Chemical species spatial distribution and relationship to elevation and snow accumulation rate over the Greenland Ice Sheet, J. Geophy. Res., in press.

Yang Q., P. A. Mayewski, S. Whitlow, M. Twickler, M. Morrison, R. Talbot, J. Dibb, and E. Linder, Global perspective of nitrate flux in ice cores, J. Geophys. Res.,100, 5113-5121, 1995.

Zielinski G. A., P. A. Mayewski, L. D. Meeker, S. Whitlow, M. S. Twickler, and $\mathrm{K}$. Taylor, Potential atmospheric impact of the Toba mega-eruption $\sim 71,000$ years ago, Geophy. Res. Lett. , 23, 837-840, 1996.

Zielinski G. A., P. A. Mayewski, L. D. Meeker, S. Whitlow, M. S. Twickler, M. Morrison, D. A. Meese, A. J. Gow, and R. B. Alley, Record of Volcanism Since 7000 B.C. from the GISP2 Greenland Ice Core and Implications for the Volcano-Climate System, Science 264, 948-952, 1994.

P.A. Mayewski, M. Twickler, Q. Yang, G.A. Zielinski, Climate Change Research Center, University of New Hampshire, Durham, NH 03824. (email: qinzhao_yang@grg.sr.unh.edu)

K.C. Taylor, Desert Research Institue, University of Nevada, Reno, NV 89506

(Received February 29, 1996; revised July 8, 1996; accepted July 11, 1996) 